\title{
VAŽNOST TJELESNOG VJEŽBANJA ZA OSOBE S DIJAGNOSTICIRANOM MULTIPLOM SKLEROZOM
}

\begin{abstract}
Sažetak
Istraživanjem se željelo utvrditi utjecaj tjelesnog vježbanja na stupanj zadovoljstva i socijalizacije te zdravstveni status polaznika programa. U istraživanje je uključeno 29 polaznika, a anketa je provedena na 29 ispitanika, od kojih je 85 \% žena, a 15\% muškaraca. Dominiraju ispitanici u dobi od 35 do 45 godina (80 \%). Istraživanjem su se iskristalizirali odgovori da su ispitanici zadovoljni programom, da im je socijalizacija i inkluzija u društvo poboljšana te da zdravstveni status nije pogoršan, sve kao posljedica provedenih tjelesnih vježbi. Temeljem provedenog istraživanja utvrđeno je da su ispitanici izuzetno motivirani za daljnju provedbu programa nakon utvrđenih blagodati provedbe programa, sukladno postavljenom cilju istraživanja i primjenom alata koji su primjereni toj društvenoj skupini. Daljnjom primjenom i prakticiranjem tjelesnog vježbanja kod osoba s MS-om moguć je pozitivan utjecaj na njihov status u društvu, kao i općenito poboljšanje svakodnevnog života.
\end{abstract}

Ključne riječi: tjelesno vježbanje, multipla skleroza, demijelinizacija, zadovoljstvo, zdravlje

\section{Uvod}

Nedostatak kretanja u suvremenim uvjetima življenja realnost je u svim područjima čovjekova djelovanja, uključivši i područje medicine. S obzirom na to da je tjelesna aktivnost čovjekova biotička potreba, potreban je veći angažman društva u cjelini, kao i svakog pojedinca koji je dužan voditi brigu o svom tjelesnom i zdravstvenom statusu. Tjelesna aktivnost ima dominantnu instrumentalnu vrijednost jer predstavlja najbolje sredstvo za postizanje i održanje zdravlja. Osim toga, tjelesna aktivnost ima i intrinzičnu vrijednost zato što omogućava realiziranje i usavršavanje čovjekovih motoričkih znanja i dostignuća (Chalas, 2009), što uz nebrigu o tjelesnom statusu

\footnotetext{
* dr. sc. Josip Miočić, Športska zajednica Grada Zadra; Sveučilište u Zadru - Odjel za kulturu i turizam, josip.miocic@szgz.hr

** Milica Komšo, dr. med., Opća Bolnica Zadar, milicakomso@gmail.com
} 
narušava cjelovitost ličnosti svakog pojedinca. Promatrajući povijesni prikaz, vidljivo je da se još od Platona i Aristotela sve do Descartesa i Kanea koji su najpreciznije objasnili dualizam u 17. stoljeću, smatra da su um i tijelo „dva različita entiteta (realna distinkcija), odnosno smatra se da je veza između uma i tijela izuzetno čvrsta i neodvojiva" (Cox, Ingersoll i Ross, 2005). Ipak, unatoč nizu znanstvenih istraživanja i preporuka koje potvrđuju pozitivnu vezu između tjelesnog vježbanja i zdravstvenog statusa pojedinca (Mišigoj-Duraković i Duraković, 2005; 2006; 2010; Duraković i Mišigoj-Duraković, 2004; 2008; 2009), između povećanja sposobnosti koncentracije, održavanja neuroloških veza u tijelu te psiholoških osobina za savladavanje stresnih situacija (Biddle i Asare, 2011; Cox, Ingersoll i Ross, 2005), mnoge institucije u području istraživanja ne poduzimaju učinkovite mjere kako bi se tjelesno vježbanje vrijednosno izjednačilo s ostalim područjima (Bakran et al., 2012).

Multipla skleroza (MS) kronična je bolest središnjeg živčanog sustava i pripada širokoj skupini bolesti koje obilježavaju razaranje mijelinskih ovojnica živčanih vlakana u mozgu i kralježničkoj moždini. Bolest je još uvijek nepoznatog uzroka i nepredvidljivog tijeka, a u suvremenom se društvu javlja u svim životnim dobima. Suvremene spoznaje i rezultati niza istraživanja ukazuju na to da je MS autoimuna bolest koja nastaje djelovanjem čimbenika, kako okoline tako i utjecajem genetske sklonosti. Cilj je ovoga rada utvrditi zadovoljstvo polaznika programom i utvrditi promjene zdravstvenog statusa polaznika te neposredno utvrditi stupanj socijalizacije, što je za tu populaciju od izuzetne važnosti. Sukladno postavljenom cilju moguće je postaviti hipotezu da su polaznici zadovoljni programom te da im je zdravstveni status i stupanj socijalizacije poboljšan primjenom tjelovježbe.

\section{Opis bolesti}

Multipla skleroza bolest je koja se javlja u svim krajevima svijeta, ali ne istom učestalošću. Bolest je najčešća u sjevernoj Europi, Sjevernoj Americi i Australiji - učestalost MS-a u tim je krajevima oko 100 oboljelih na 100000 stanovnika. Bolest se ne javlja u domorodaca u Americi, Kanadi i Australiji ili je izuzetno rijetka. Slično je i s učestalosti bolesti u Eskima, Laponaca i Roma (Bakran et al., 2012). U Hrvatskoj se sve više utvrđuje učestalost i porast bolesti, što je možda i uzrokovano suvremenom dijagnostikom koja se primjenjuje. Etiologija MS-a još uvijek je nejasna te prema tome spada u skupinu neriješenih problema suvremene medicine. Kako je već prethodno u radu navedeno, osnovna karakteristika multiple skleroze je dominantna upala mijelinske ovojnice živaca SŽS-a, dok su sama živčana vlakna u početku relativno pošteđena. Zbog toga se bolest ubraja u veliku grupu tzv. demijelinizacijskih bolesti. Periferni živci, tj. živci koji prenose živčane podražaje prema periferiji (inerviraju mišiće glave i tijela) također imaju mijelinsku ovojnicu, no u multiploj sklerozi periferni živčani sustav ostaje pošteđen. 
Simptomi bolesti javljaju se zbog oštećenja mijelinske ovojnice. Ovisno o lokalizaciji i „opsegu oštećenja ovojnice nastaje oštećenje motorike (primjerice poremećaj kretanja ili slabosti motoričke snage ekstremiteta), oslabljen je osjet, smanjuje se vidna oštrina, poremećena je ravnoteža, kontrola sfinktera i dr." (Chalas, 2009). Mijelinska ovojnica omogućava brzo širenje živčanih impulsa, ali i zaštitu i prehranu živčanih vlakana, pa njezino oštećenje uzrokuje ogoljelost i postupno oštećenje i degeneraciju živčanih vlakana. Oštećenje mijelinske ovojnice onemogućava adekvatno provođenje živčanih impulsa: pri manjem oštećenju mogu se provoditi neki sporiji impulsi, a ne provode se impulsi brze frekvencije, što se očituje različitim intenzitetom neurološkog ispada. U MS-u imuni sustav napada mijelin. Mijelin je masna bijela tvar koja oblaže živčane niti i živčane stanice te omogućuje prijenos podražaja, tj. komunikaciju između mozga i ostatka tijela. Na mjestima gdje nestane mijelin dolazi do stvaranja ožiljaka, tzv. demijeliziranih plakova, što dovodi do usporenja ili blokade prijenosa podražaja između živčanih stanica.

Znakovi bolesti javljaju se najčešće između 20. i 50. godine života, a žene prema dosadašnjim istraživanjima dva puta češće obolijevaju od muškaraca. Iako je još uvijek uzrok MS-a nepoznat, najprihvaćenija je teorija da je MS uzrokovan kombinacijom djelovanja okoliša, genetike i nenormalnosti u imunom sustavu koji su okidači bolesti. Simptomi su neurološki, psihijatrijski i oftalmološki, pojedinačni ili međusobno povezani (Bašić Kes, 2013). Mogu biti senzorički i motorički, s tim da su početni simptomi najčešće subjektivne smetnje smanjenja osjeta što dovodi do dvoslika, gubljenje snage u jednom ili više ekstremiteta, poremećaj ravnoteže i vrtoglavice, smetnje kontrole mokrenja i stolice., Prema Brinar i Patelin (2003) osnovni simptomi su nistagamus, intencijski tremor i dizartrija (skandirajući govor).

Dalje s razvojem bolesti mogući su i poremećaji koordinacije pokreta, tremor, poremećaj govora, ukočenost mišića, pa čak i mentalni poremećaji. Vidljivo je dakle da su mogući simptomi različiti, a tijek bolesti suvremena medicina s naporom može teško predvidjeti. Primjerice, neke osobe s MS-om mogu izgubiti sposobnost samostalnog kretanja i govora, dok drugi mogu doživjeti duga razdoblja remisije u kojima nema novih simptoma. S tim da je nužno voditi brigu o cjelokupnom statusu liječenja pod nadzorom specijalista, od kojih jedan može biti i kineziolog. MS prema obliku dijelimo na: „relapsno-remitentnu (rrms), sekundarno progresivnu (spms), primarno progresivnu (ppms) i progresivno-relapsnu (prms)" (Brinar i Patelin, 2003). MS danas nije moguće izliječiti, a cilj je liječenja skratiti akutna pogoršanja bolesti ili relapse, smanjiti učestalost akutnih pogoršanja i ublažiti simptome bolesti.

Razlikujemo tri vrste liječenja: liječenje akutnog napada bolesti ili relapsu, liječenje imunomodulacijskom terapijom i liječenje simptoma. Uz sve ostale primarne načine liječenja putem „terapija lijekovima (npr. imunomodulacijskog liječenja), redovito tjelesno vježbanje preporučuje se čak i osobama s uznapredovalom bolešću, jer 
kondicija srca i mišića smanjuje spastičnost, sprečava razvoj kontraktura a ima i neophodnu psihološku korist” (Habek, 2019). Stoga iz aspekta ovog rada valja naglasiti da bi bolesnici trebali voditi normalan život i imati tjelesne aktivnosti sve dok je to moguće, s tim da trebaju izbjegavati prekovremeni rad, umor i izloženost velikoj vrućini.

\subsection{Epidemiologija}

Prevalencija multiple skleroze od 2003. iznosi 167 oboljelih na 100000 stanovnika. To je značajno povećanje u odnosu na 1963. u kojoj je prevalencija bila 62 oboljela na 100000 stanovnika (Lund et al., 2014). To ukazuje na to da MS postaje sve veći problem u svijetu. Od 1983. do 2002. prosječna godišnja incidencija (broj novih slučajeva oboljelih od multiple skleroze) bila je 4,5 / 100000 (Lund et al., 2014), što predstavlja zabrinjavajući podatak koji je možda vezan i za suvremenu dijagnostiku.

\section{Program kombiniranog treninga za osobe s multiplom sklerozom}

Tjelesno vježbanje i kineziterapija može se koristiti u različitim medijima, i na kopnu i u vodi (hidrokineziterapija). Neovisno o tome u kojem se mediju provodi kineziterapija, može se realizirati kroz različite vrste trenažnih aktivnosti. To su aerobni i anaerobni trening, trening snage, trening fleksibilnosti, trening koordinacije (uključujući ravnotežu i preciznost), trening brzine, trening yoge, trening pilatesa i kombinirani trening (Miočić, Jurinić i Špralja, 2019). Kombinirani trening provodi se u nezdravstvenoj ustanovi i sportskoj dvorani pod vodstvom kineziologa, uz nadzor i vanjsku kontrolu neurologa. Kombinirani trening provodi se dvaput tjedno. Program se provodi umjerenim intenzitetom, odnosno prema Borgovoj skali (12 - 20): hodanje, trčanje, zatim jačanje većih mišićnih skupina kroz izometrične, koncentrične i ekscentrične kontrakcije te statičko, dinamičko, aktivno i pasivno istezanje svih regija tijela. Trajanje pojedinačnog treninga je 45 minuta, a trajanje cijelog programa je 24 tjedna (Swain, Clinton i Brawner, 2014). Cilj je programa omogućiti svim polaznicima nesmetano obavljanje tjelesne aktivnosti s ciljem prevencije i održavanja zdravstvenog statusa polaznika. Program je prilagođen morfološkim karakteristikama, motoričkim sposobnostima i zdravstvenom statusu svakog polaznika koji su utvrđeni upitnikom.

\section{Metode}

Za potrebe ispitivanja zadovoljstva polaznika programom koristila se metoda anketiranja te je kreiran odgovarajući anketni upitnik. Anketa predstavlja kvantitativni 
oblik istraživanja putem kojeg su prikupljeni različiti stavovi i mišljenja (zadovoljstvo) polaznika programa te se mogu utvrditi promjene zdravstvenog statusa polaznika.

\subsection{Ispitanici}

Uzorak ispitanika čini 29 polaznika programa tjelesnog vježbanja za osobe s MS-om koji provodi stručna služba Sportske zajednice grada Zadra, s područja grada Zadra i Zadarske županije. Program je planiran i provođen u trajanju od 24 tjedna. Svim polaznicima dijagnosticiran je MS na odjelu za neurologiju Opće bolnice Zadar. U radu su analizirani rezultati postavljenog anketnog upitnika kojim je obuhvaćeno 29 polaznika, to jest svi polaznici koji su bili u tom trenutku prisutni na aktivnosti. Anketni upitnik polaznici su ispunili po održanom treningu u za to adekvatnom prostoru. Anketni upitnik je konstruiran, a zatim testiran na grupi od tri polaznika, da bi zatim njegovu ispunjavanju pristupili svi ostali sudionici istraživanja. Anketni upitnik sastoji se od 9 pitanja grupiranih u dvije cjeline, opću i istraživačku cjelinu. Prvi dio anketnog upitnika odnosi se na opće podatke, dok se u drugom dijelu nalaze pitanja koja imaju za cilj odgovoriti na postavljene hipoteze u radu. Nakon provedbe anketiranja, ispunjeni anketni upitnici u tiskanom obliku uneseni su u program LimeSurvey te zatim eksportirani u specijaliziran statistički program za obradu podataka SPSS na daljnju statističku obradu.

\section{Rasprava}

Nakon obavljenog anketnog istraživanja izvršila se analiza dobivenih odgovora ispitanika. Rezultati su pokazali kako je u istraživanju sudjelovalo više žena (75 \%) nego muškaraca ( $25 \%$ ) te da prevladavaju oni između 35 i 45 (80 \% ispitanika) godina starosti. Grupom pitanja koja su se odnosila na zadovoljstvo polaznika programom iskristalizirao se odgovor da je program u potpunosti zadovoljavajući, što je vidljivo na primjeru pitanja (tablica 1) koliko ste zadovoljni programom? Najveći broj, 82,14\%, ispitanika smatra da je program u potpunosti zadovoljavajući, a njih 3,57 \% drži ga djelomično zadovoljavajućim. Dok znatno manji postotak ispitanika $(3,57 \%)$ smatra da je program niti zadovoljavajući niti nezadovoljavajući. Djelomično nezadovoljavajućim smatra ga $7,14 \%$ ispitanika te da je u potpunosti nezadovoljavajući smatra 3,57 \% ispitanika.

Tablica 1. Rezultati pitanja koliko ste zadovoljni programom?

\begin{tabular}{|ccccc|}
\hline $\begin{array}{c}\text { U potpunosti } \\
\text { nezadovoljni }\end{array}$ & $\begin{array}{c}\text { Djelomično } \\
\text { nezadovoljni }\end{array}$ & $\begin{array}{c}\text { Niti zadovoljni niti } \\
\text { nezadovoljni }\end{array}$ & $\begin{array}{c}\text { Djelomično } \\
\text { zadovoljni }\end{array}$ & $\begin{array}{c}\text { U potpunosti } \\
\text { zadovoljni }\end{array}$ \\
\hline $3,57 \%$ & $7,14 \%$ & $3,57 \%$ & $3,57 \%$ & $82,14 \%$ \\
\hline
\end{tabular}


Potom se na grupom pitanja koja su se odnosila na zdravstveni status pojedinca i stupanj socijalizacije iskristalizirao odgovor (tablica 2) da su polaznici poboljšali svoj zdravstveni status i stupanj socijalizacije otkada prakticiraju tjelovježbu (75\%), u odnosu na odgovor da im je zdravstveni status i socijalizacija nepromijenjena (17,86 \%) ili lošija $(7,14 \%)$.

Tablica 2. Sumarni rezultati grupe pitanja o stanju zdravstvenog statusa i stupnju socijalizacije po prakticiranju tjelovježbe

$\begin{array}{ccc}\text { Lošije } & \text { Nepromijenjeno } & \text { Poboljšano } \\ 7,14 \% & 17,86 \% & 75 \%\end{array}$

Pitanjem kakav je status vaših simptoma MS-a nakon ciklusa tjelesnog vježbanja jasno se iskristalizirao odgovor da su kod 82,14\% ispitanika smanjeni simptomi, kod $14,29 \%$ ispitanika su nepromijenjeni, a 3,57 \% ispitanika navelo je da su im se simptomi pogoršali.

Tablica 3. Rezultati pitanja kakav je status vaših simptoma MS-a nakon ciklusa tjelesnog vježbanja?

$\begin{array}{ccc}\text { Pogoršali su se } & \text { Nepromijenjeni su } & \text { Smanjili su se } \\ 3,57 \% & 14,29 \% & 82,14 \%\end{array}$

Dobar odaziv ispitanika iz anketnog upitnika proizišao je iz želje, odnosno motiviranosti polaznika programa za njegovom daljnjom provedbom i napretkom te njihove intencije da im se i dalje osigura „pažnja i individualnost” što im program omogućuje. Temeljem provedenog istraživanja i rezultata proizašlih iz anketnog upitnika koji su ispunili polaznici programa, otvorilo se nekoliko tema koje su potaknute pitanjima iz anketnog upitnika kojima se valja pozabaviti u budućnosti (npr. organiziranje tjelovježbe sukladno osobnim preferencijama).

\section{Zaključak}

Ovim je istraživanjem promatrano zadovoljstvo polaznika programom te stupanj socijalizacije i zdravstveni status polaznika po održanom ciklusu tjelesnog vježbanja, odnosno tjelesnim promjenama simptoma MS-a. Metodom anketnog upitnika ispitani su različiti stavovi i mišljenja (zadovoljstvo) polaznika programom te stupanj promjena zdravstvenog statusa i stupnja socijalizacije. Temeljem provedenog istraživanja i rezultata proizašlih iz anketnog upitnika vidljivo je da su polaznici izuzetno zainteresirani za tjelesnu aktivnost te da rezultati istraživanja ukazuju na blagodat kod 
izraženih tjelesnih simptoma ispitanika. Zdrav način života koji uključuje tjelesno vježbanje, nedjeljiv je i jedan od osnovnih preduvjeta za održavanje i razvijanje kako tjelesnog tako i psihičkog zdravlja ljudi. Permanentno sudjelovanje u tjelesnim aktivnostima kroz organizirane ili neplanske aktivnosti pridonose doživljaju boljeg, stabilnijeg te primjerenijeg života čovjeka. Sukladno postavljenom cilju i rezultatima anketnog upitnika možemo potvrditi hipotezu da su polaznici zadovoljni programom te da im je zdravstveni status i stupanj socijalizacije poboljšan primjenom organiziranog tjelesnog vježbanja. S time da je prakticiranjem tjelesnog vježbanja kod osoba s dijagnosticiranim MS-om posredno moguć utjecaj na mogućnost što duljeg kvalitetnijeg samostalnog života, što je od izuzetne važnosti za te osobe, pa tako i za mogućnost inkluzije u društvo. U ovom interdisciplinarnom prostoru nužno je svim stručnjacima, posebice u području medicine, omogućiti posjedovanje specifičnih dijagnostičkih alata i kompetencija koje mogu pomoći osobama s dijagnosticiranim MS-om. Uspjehom u tome da svaki pojedinac u što većoj mjeri pronađe sreću i smisao života, postići će se i pozitivan transfer svakodnevnog života čovjeka, dugoročno poboljšanje zdravstvenog statusa te smanjenje zdravstvenih troškova društva u prostoru osoba s dijagnosticiranom multiplom sklerozom.

\section{Literatura}

1. Bašić Kes, V., Cesarik, M., Zadro Matovina, L., Zavoreo, I., Ćorić, L., Drnasin, S. i Demarin, V. 2013. Uloga komplementarne i alternativne medicine u terapiji multiple skleroze. Acta Clinica Croatica, 52 (4): 464-470.

2. Bakran, Ž., Varjačić, M. i Tršinski, D. 2012. Rehabilitacija osoba s multiplom sklerozom. Medicinski vjesnik, 44 (1-4): 117-124.

3. Berčić, B. i Đonlić, V. 2009. Tjelesno vježbanje u suvremenim uvjetima života. Filozofska istraživanja, 115 (29): 449-460.

4. Brinar, V. i Petelin, Ž. 2003. Multipla skleroza-klinička slika, dijagnostika i liječenje. Medix: specijalizirani medicinski dvomjesečnik, 9 (50): 66-70.

5. Biddle, S. J. i Asare, M. 2011. Physical activity and mental health in children and adolescents: a review of reviews. British journal of sports medicine, 45 (11): 886-895.

6. Cox, J. C., Ingersoll, Jr, J. E. i Ross, S. A. 2005. A theory of the term structure of interest rates. In Theory of Valuation, 129-164.

7. Chałas, R. 2009. Calcium and potassium saliva concentration in patients with multiple sclerosis. Acta stomatologica Croatica, 43 (1): 34-38.

8. Đonlić, V., Berčić, B., Perak, B., Smojver Ažić, S. i Takšić, V. 2015. Multidisciplinarno poimanje tjelesnog vježbanja. Filozofska istraživanja, 35 (3): 493-508.

9. Habek, M. 2019. Novi pristup u liječenju multiple skleroze. Medicus, 28 (1 Neurologija): 33-39.

10. Rimmer, J. i Lund, V. J. 2014. A modified technique for septodermoplasty in hereditary hemorrhagic telangiectasia. The Laryngoscope, 124 (1): 67-69. 
11. Mišigoj-Duraković, M., Heimer, S. i Matković, B. R. 1999. Utvrđivanje razine tjelesne aktivnosti u javnozdravstvenim studijama. U: Tjelesno vježbanje i zdravlje, ur. MišigojDuraković et al., 12-14. Zagreb: Fakultet za fizičku kulturu Sveučilišta u Zagrebu.

12. Miočić, J., Jurinić, S. i Špralja, R. 2019. Tjelesna aktivnost - vježbanje u trećoj životnoj dobi $65^{+}$. 28. Ljetna škola kineziologa Republike Hrvatske, 331-337.

13. Prskalo, I. i Sporiš, G. 2016. Kinesiology. Zagreb: Školska knjiga, Učiteljski fakultet Sveučilišta u Zagrebu, Kineziološki fakultet Sveučilišta u Zagrebu.

14. Swain, D. P., Brawner, C. A. i American College of Sports Medicine. 2014. ACSM's resource manual for guidelines for exercise testing and prescription. Wolters Kluwer Health/Lippincott Williams and Wilkins.

\section{The importance of physical exercise in persons with diagnosed multiple sclerosis \\ Abstract}

The study sought to determine the impact of exercise on the level of satisfaction and socialization and health status of the program participants. The study included 29 participants, and the survey was conducted on 29 respondents, of whom $85 \%$ were women and $15 \%$ were men. It was dominated by respondents aged 35 to 45 years ( $80 \%)$. The survey crystallized the answers that the respondents were satisfied with the program, that their socialization, inclusion in society had improved, and that their health status had not deteriorated due to the physical exercises performed. Based on the conducted research, it was found that the respondents are extremely motivated for further implementation of the program based on the established benefits of program implementation, in accordance with the set research goal and using tools that are appropriate for this social group of our citizens. Continued use and practice of physical exercise in people with MS may have a positive impact on their status in society, which will contribute to the positive transfer of daily life of an individual in society in a variety of problems in the area of people diagnosed with multiple sclerosis.

Key words: exercise, multiple sclerosis, demyelination, pleasure, health. 